\title{
Responses of Vegetation and Cattle to Various Systems of Grazing on Seeded and Native Mountain Rangelands in Eastern Utah
}

\author{
W.A. LAYCOCK AND P.W. CONRAD
}

\section{Abstract}

Several grazing systems were compared on the Diamond Mountain Cattle Allotment of the Ashley National Forest in Utah. The area is about $8,000 \mathrm{ft}$ in elevation and receives $20-25$ inches of precipitation annually. On native sagebrush-grass range, a comparison of summer-long (July-September) grazing every year, summer-long in alternate years, and 3-unit rest-rotation systems revealed no differences between systems in cover, production, or species composition of vegetation after 7 years of grazing. Average daily gains of cattle over the entire period were the same for all systems. During the period of study on this range, which was in fair to good condition and grazed at a moderate intensity, rest-rotation was not a better system than summer-long grazing. The key to this lack of difference was management. Rest-rotation systems require intensive management of water, salt, riding, etc. All units in both systems in the study had good distribution of water and salt and adequate riding to insure uniform cattle distribution. The unit grazed summer-long every year received the same degree of management and thus remained as productive as ranges under restrotation management. On seeded units of the allotment, heavy grazing in June in alternate years increased production on areas dominated by crested wheatgrass and smooth brome.

Practical and efficient methods of managing cattle on highelevation ranges of the Intermountain area are needed. This study was started in 1959 and continued through 1967 and was designed to test two systems of spring (June) grazing on seeded mountain rangeland and three systems of summer grazing on native rangeland. The relative effects of the grazing systems on forage production, amount and pattern of utilization, ground cover, and cattle production were compared. It was a cooperative effort of the Diamond Mountain Cattle Association and the Intermountain Forest and Range Experiment Station and the Ashley National Forest of the U.S. Forest Service.

\section{Experimental Area}

The study was conducted on the Diamond Mountain Cattle Allotment approximately 25 miles north of Vernal, Uintah County, Utah, on the Ashley National Forest. The allotment is on the plateau on the east end of the Uinta Mountains. Elevations on the allotment vary from 7,000 feet on the southeast to 8,200 feet on the northwest. The allotment is predominately rolling tableland bordered on the southwest and dissected on the south side by steep canyons. Precipitation records from the Kings Cabin storage gauge (4 miles west of the allotment but slightly higher elevation) indicate an average annual precipitation of 24.0 inches for an 11-year period, 1957-1967.

The allotment is representative of the upper sagebrush-grass and lower aspen zones throughout the Intermountain area. The allot-

\footnotetext{
Authors are at present with the U.S. Department of Agriculture, Agricultural Research-Science and Education Administration, Colorado State University, Fort Collins, Colorado; U.S. Forest Service, Flathead National Forest, Kalispell, Montana.
}

Manuscript received July 6, 1979. ment covers approximately 11,000 acres of which 9,935 acres are usable by cattle. It is divided into 7 pastures or units ranging from 1,105 to 1,920 acres in size.

The most extensive vegetation type on most of the rolling ridges and tablelands on the allotment is a sagebrush-grass dominated by big sagebrush (Artemisia tridentata spp. vaseyana) with an understory of grasses and forbs. Other vegetation types on different topographic sites include: aspen (Populus tremuloides) with a dense understory of grasses and sedges on some drainage ways and gentle north-facing slopes; mixed shrub [sagebrush, bitterbrush (Purshia tridentata), serviceberry (Amelanchier alnifolia), snowberry (Symphoricarpos oreophilus), and other shrubs] on southfacing slopes and in canyons; and swales along drainageways dominated by Kentucky blue grass (Poa pratensis). The native units were in fair to good range condition at the start of the study.

Two of the units were seeded with introduced grasses in the mid-1950's. One of the seeded units was predominately crested wheatgrass (Agropyron cristatum and $A$. desertorum) and will be referred to as the "crested wheatgrass unit." The other seeded unit had a mixture of crested wheatgrass and smooth brome (Bromus inermis) on upland sites and almost pure smooth brome on swale sites. This will be referred to as the "crested-brome unit."

The soils on the allotment are loams to clay loams derived mainly from sedimentary rocks of the Browns Park and Morgan formations. The following summarizes the characteristics of the top 4 inches of soil (Laycock and Conrad 1967):

\begin{tabular}{lcc} 
& \multicolumn{2}{c}{ Location } \\
\cline { 2 - 3 } Gravel $(\%)$ & Upland & Swale \\
Bulk density $(\mathrm{g} / \mathrm{cc})$ & $9-10$ & $4-6$ \\
Organic matter $(\%)$ & $1.16-1.24$ & $1.04-1.10$ \\
& $4-6$ & $5-8$
\end{tabular}

\section{Methods}

\section{Grazing Treatments}

Each year 506 mature cattle and approximately 350 calves grazed on the allotment for an average of 126 days (June 2-October 5). In 1959 all units were grazed at a uniform rate and each was evaluated for grazing capacity. Stocking rates were then set for the grazing treatments to be compared. The rates were designed to remove 30 percent of the grass when all years were averaged, including any years of rest.

The grazing treatments listed in Table 1 started in 1960 and continued through 1966, on both seeded and native range. On the seeded range, the crested wheatgrass unit was grazed with all of the cattle during even-numbered years for about the first 34 days of grazing. The crested-brome unit was grazed similarly during oddnumbered years; then it was grazed lightly with about one-sixth of the cattle for the balance of the summer.

After the 34-day period on the seeded units, the cattle grazed the native range for the balance of the summer in the following grazing systems: (1) summer-long grazing every year; (2) three-unit rest- 
rotation grazing; and (3) summer-long grazing in alternate years. The animals in the three-unit rest-rotation system grazed for approximately 45 days in one unit and then were moved to another unit. The third unit in this system was rested from grazing each year. The early summer, late summer, and rest treatments were rotated each year. Cattle assigned to summer-long systems remained in the same unit the entire summer.

Water was available at several locations in each unit from live streams and beaver ponds or from impoundments that collected water from snow melt or rain. Rock salt and mineral supplement were located throughout each unit (away from water) to aid in the distribution of animals.

\section{Cattle Response}

To determine the responses of cattle to the various systems of grazing, approximately 40 nursing cows and 30 yearlings were weighed during each of the five grazing seasons from 1961-1965. An average of 20 calves were weighed during each of four seasons from 1961-1964. No calves were weighed in 1965. The same marked animals were weighed four times during the grazing season: (1) when the cattle entered the allotment (about June 2); (2) when cattle were removed from the seeded pastures and divided into three groups (about July 4); (3) when the cattle in the threeunit rest-rotation system changed units (about August 11); and (4) just before the cattle left the allotment (about October 4). Weighing dates varied somewhat from year to year due to range readiness and degree of forage utilization. Cattle were weighed immediately after gathering without a shrinkage period.

The cattle weighed were mostly registered Herefords and were representative of about $60 \%$ of the cattle on the allotment. The cows averaged about 6 years of age. The calves were 3-4 months old and the yearlings were 15-16 months old at the time they entered the allotment.

\section{Vegetation Sampling on Study Plots}

Several study plots were established in each unit in 1959, each consisting of an exclosure $(33 \mathrm{ft} \times 33 \mathrm{ft}$ ) and an adjacent (within 50 $\mathrm{ft}) 50 \mathrm{ft} \times 50-\mathrm{ft}$ marked area open to grazing. In some of the study plots vegetation was sampled in 1959 or 1960, but an inventory of a majority of plots ( 2 to 6 in each unit) in the same year was not completed until 1961. An inventory of the same plots sampled in
1961 was also done in 1967 , the year following the last year of the grazing treatments. All comparisons of vegetation trends are presented for the years 1961-1967. The number of study plots sampled in each unit in 1961 and 1967 is shown in Table 1. Sampling was done prior to grazing in most cases. Estimates were adjusted for utilization in the few instances where grazing occurred before sampling.

Green weight (peak aboveground standing crop) was estimated for each species within one-foot-square quadrats. Green weight was later converted to weight on an oven-dry basis. Data were taken on 50 quadrats located on a stratified random basis ( 25 in the exclosure and 25 in the grazed area) every time each study plot was sampled. Each sample of 25 quadrats resulted in the following range of standard errors of the mean total grass production at the 95\% confidence level:

\begin{tabular}{lcc} 
& \multicolumn{2}{c}{$\%$ of Mean } \\
\cline { 2 - 3 } Vegetation Type & Range & Average \\
Sagebrush & $14-46$ & 22.5 \\
Seeded & $13-37$ & 22.0 \\
Aspen & $20-66$ & 41.4 \\
Native swale & $23-43$ & 26.6
\end{tabular}

For individual species, confidence intervals would be much larger.

Total cover of the aerial portion of herbaceous plants, litter, and bare ground (including rock) in each quadrat was also estimated. Where shrubs were present, the amount of each quadrat covered by the canopy was also estimated independently. Cover was defined as the vertical projection on the ground of all live vegetation.

\section{Herbage Production and Utilization Surveys}

Before grazing each year, total grass production in each unit was mapped by production classes using a reconnaissance method. This was done independently from the more detailed sampling of the study plots previously described. The total acreage covered by each production class multiplied by the midpoint of that production class (in pounds per acre) enabled us to estimate total pounds of grass available for grazing in the unit excluding any growth or regrowth that took place during the grazing period.

The percentage utilization of each grass species was ocularly estimated using the method described by Pechanec and Pickford (1937) immediately after cattle grazed in each unit each year. Utilization cages were placed near each study plot prior to grazing.

Table 1. Average utilization (\%) of the total grass production on the sampled study plots and in each entire unit, Diamond Mountain Cattle Allotment 1960-1965'.

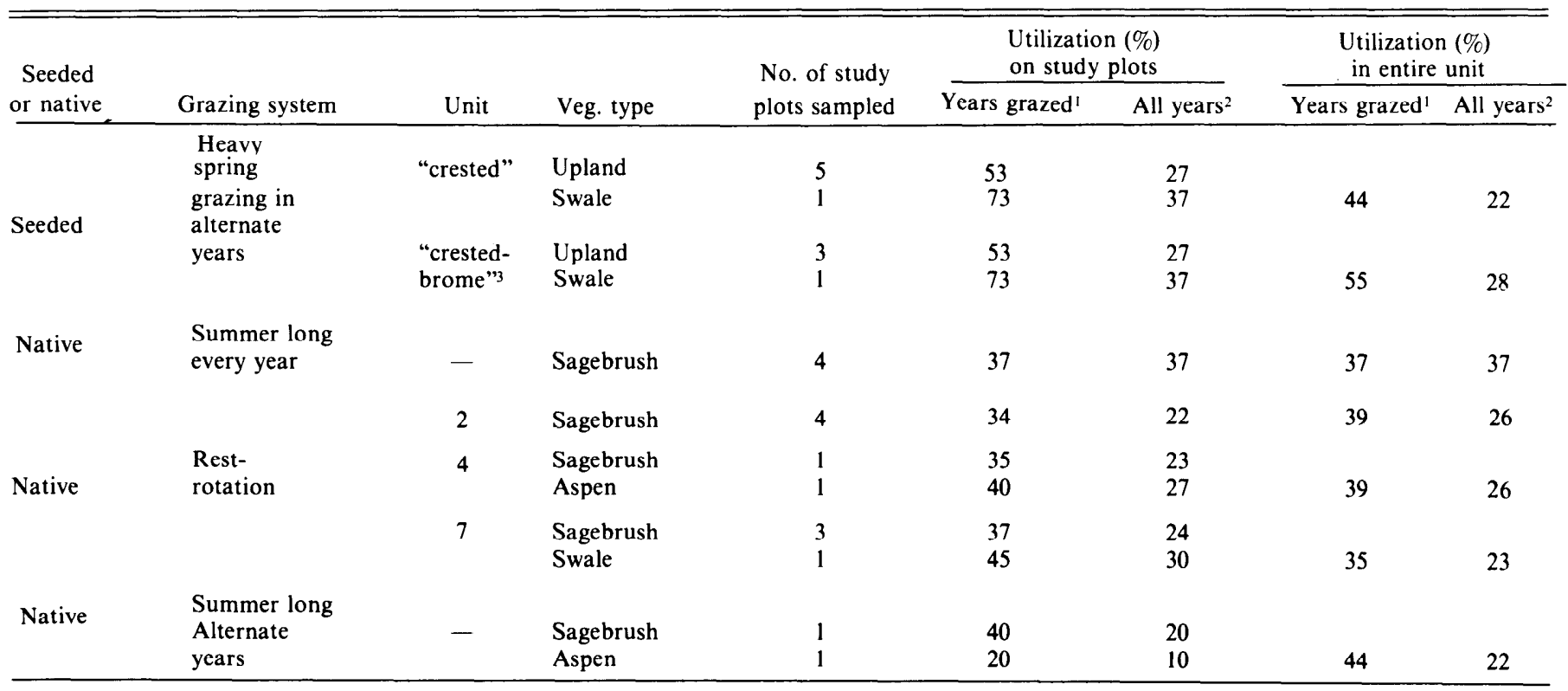

'Average utilization for the years the unit was actually grazed

${ }^{2}$ Average of all years including " 0 " utilization in years not grazed. First o years is used to give an unbiased estimate for both 2 -unit and 3-unit systems.

${ }^{3}$ This unit also received light summer-long grazing in the same years it was grazed heavily in the spring. 
We trained for estimating utilization by clipping these protected areas at various levels. The entire unit was also surveyed by a reconnaissance method as soon as possible after grazing to determine total utilization of all grass produced in the unit. Utilization of the total grass production was mapped by classes. Overlays of production and utilization maps enabled us to estimate the total pounds of grass removed and to calculate a weighted average percent utilization for the unit. Because production of regrowth during the grazing period was not taken into acount, the utilization figures for each unit probably are slightly too low.

\section{Results}

The seeded units received much heavier use in the years they were grazed than most of the native units. Average utilization of the total grass production in the seeded units was 44 to $55 \%$ in the years grazed but 22 to $28 \%$ when averaged over all years (Table 1 ). Utilization in the grazed portion of the study plots generally was similar to the average for the entire unit (Table 1). However, in both seeded units average utilization was considerable higher in swale study plots than in upland plots.

Prior to the study, rather low utilization of crested wheatgrass had been a problem in the crested-brome unit. Under moderate grazing on upland sites in $1959,40 \%$ of the smooth brome was utilized while only $20 \%$ of the crested wheatgrass was used. In the swales, brome was heavily utilized $(80 \%)$. Under heavy grazing in alternate years, heavy utilization of brome $(75 \%)$ continued. On upland sites, however, use of crested wheatgrass (48\%) was about two and one-half times greater than it had been in 1959 while use of brome $(58 \%)$ was only moderately higher. Thus, the heavy grazing resulted in much better utilization of the crested wheatgrass on upland sites than had been achieved under moderate grazing.

In the native units, average utilization in the years grazed was the same $(37 \%)$ for both the rest-rotation and the summer-long every year systems and slightly higher $(44 \%)$ for the unit grazed summerlong in alternate years. When years of rest were included in the average, the system grazed summer-long every year received the heaviest grazing rate $(37 \%)$ while the rest-rotation system averaged $25 \%$ and the system grazed summer-long in alternate years averaged $22 \%$.

\section{Trends in Production, 1961-1967 \\ Native Vegetation}

Patterns of herbage production changes in the sagebrush and mixed shrub vegetation types were generally similar for the three grazing systems (Table 2). The differences that did occur are difficult to explain and seem to be caused by factors other than differences in the grazing systems. Trends in production in the grazed areas were similar to those in the exclosures, indicating that the various grazing systems had little effect on composition or production of vegetation.

Only the rest-rotation and the summer-long alternate year systems contained study plots in vegetation types other than sagebrush-grass and mixed shrub. However, the aspen type sampled in those two grazing systems had different species in the understory so comparisons were difficult.

\section{Seeded Units}

Total grass production in the seeded units increased considerably between 1961 and 1967 on almost all plots (Table 3). The increase was statistically significant $(P \leq .05)$ as determined by a $t$ test of grass production on all study plots in 1961 compared to production in 1967. Much of this increase undoubtedly was due to more precipitation in the year immediately preceding the vegetation sampling in 1967 than in 1961. At the King's Cabin storage gage, precipitation for the preceding July-June period was 17.1 inches in 1960-61 and 28.1 inches in 1966-67. It is interesting to note that production of the seeded grasses reflected this difference in precipitation while production of the native grasses in 1967 was not statistically significantly different from production in 1961 .

Except for the swale area in the crested wheatgrass unit, production increased as much as or more in the grazed areas than it did in the exclosures indicating that the heavy use in alternate years was

Table 2. Herbage production (peak aboveground standing crop) and ground cover on native sagebrush and mixed shrub vegetation in ungrazed exclosures and areas grazed under three different management systems, Diamond Mountain Cattle Allotment, 1961-1967.

\begin{tabular}{|c|c|c|c|c|c|c|c|c|c|c|c|}
\hline \multirow[b]{3}{*}{ Species } & \multicolumn{4}{|c|}{ Summer-long every year } & \multicolumn{4}{|c|}{ 3-unit rest-rotation } & \multicolumn{3}{|c|}{ Summer-long alt. years } \\
\hline & \multicolumn{2}{|c|}{ Exclosures } & \multicolumn{2}{|c|}{ Grazed } & \multicolumn{2}{|c|}{ Exclosures } & \multicolumn{2}{|c|}{ Grazed } & \multicolumn{2}{|c|}{ Exclosures } & Grazed \\
\hline & 1961 & 1967 & 1961 & 1967 & 1961 & 1967 & 1961 & 1967 & 1961 & 1967 & 1961 \\
\hline
\end{tabular}

Herbage production (lb/acre)

Agropyron spp. (mainly A. smithii,

A. dasystachyum)
Carex spp.
Poa. spp. (mainly $P$. fendleriana, $P$.

secunda)

Sitanion hystrix

Stipa columbiana

Stipa comata

Other Grasses

Achillea millefolium

Antennaria rosea

Arenaria congesta

Balsamorhiza spp.

Eriogonum umbellatum

Lupinus caudatus

Phlox spp.

Other Forbs

.

$\begin{array}{rrrrrrrrrrrr}5 & 24 & 9 & 20 & 57 & 55 & 26 & 45 & 2 & 30 & 21 & 54 \\ 6 & 11 & 2 & 8 & 23 & 25 & 15 & 11 & 58 & 74 & 46 & 78 \\ 189 & 75 & 137 & 97 & 159 & 132 & 119 & 136 & 63 & 33 & 87 & 27 \\ 97 & 40 & 43 & 24 & 13 & 26 & 13 & 7 & 47 & 24 & 47 & 55 \\ 75 & 32 & 8 & 30 & 10 & 7 & 5 & 18 & 4 & 23 & 14 & 36 \\ 370 & 285 & 262 & 251 & 88 & 114 & 65 & 106 & 111 & 214 & 71 & 184 \\ 8 & 20 & 36 & 48 & 49 & 48 & 38 & 67 & 15 & 20 & 7 & 71 \\ 12 & 24 & 3 & 6 & 2 & 3 & 2 & 4 & 0 & 0 & 2 & 12 \\ 4 & 8 & 1 & 3 & 17 & 17 & 7 & 28 & 5 & 15 & 13 & 32 \\ 34 & 25 & 36 & 21 & 19 & 13 & 22 & 22 & 36 & 38 & 40 & 34 \\ 0 & 1 & 9 & 16 & 93 & 188 & 80 & 113 & 0 & 0 & 0 & 0 \\ 26 & 1 & 4 & 2 & 3 & 2 & 4 & 1 & 16 & 28 & 13 & 4 \\ 8 & 64 & 51 & 60 & 7 & 16 & 17 & 14 & 2 & 10 & 27 & 37 \\ T & 2 & 0 & 1 & 69 & 59 & 47 & 32 & 102 & 60 & 157 & 117 \\ 73 & 159 & 135 & 168 & 207 & 286 & 206 & 294 & 184 & 267 & 174 & 211 \\ 750 & 487 & 497 & 478 & 399 & 407 & 281 & 390 & 300 & 418 & 293 & 505 \\ 157 & 284 & 239 & 277 & 417 & 584 & 385 & 508 & 345 & 418 & 426 & 447 \\ 907 & 771 & 736 & 755 & 816 & 991 & 666 & 898 & 645 & 836 & 719 & 952\end{array}$

Total grass prod.

Total forb prod.

Total herbage prod.

\begin{tabular}{rrrr} 
& 189 & 75 & 137 \\
97 & 40 & 43 \\
75 & 32 & 8 \\
370 & 285 & 262 \\
8 & 20 & 36 \\
12 & 24 & 3 \\
& 4 & 8 & 1 \\
& 34 & 25 & 36 \\
0 & 1 & 9 \\
26 & 1 & 4 \\
& 8 & 64 & 51 \\
$\mathrm{~T}$ & 2 & 0 \\
73 & 159 & 135 \\
& 750 & 487 & 497 \\
157 & 284 & 239 \\
907 & 771 & 736 \\
\hline
\end{tabular}

Cover (\%)

Shrubs (mainly Artemisia tridentata)

Total plant cover

Litter

$\begin{array}{rrr}8 & 16 & 5 \\ 41 & 42 & 23 \\ 55 & 52 & 65 \\ 4 & 6 & 12\end{array}$

$\begin{array}{rrrr}13 & 12 & 13 & 15 \\ 41 & 38 & 44 & 35 \\ 44 & 54 & 40 & 54 \\ 15 & 8 & 16 & 11\end{array}$

13
42
34
24 
Table 3. Herbage production (peak aboveground standing crop) and ground cover on seeded units grazed heavily in alternate years, Diamond Mountain Cattle Allotment, 1961-1967.

\begin{tabular}{|c|c|c|c|c|c|c|c|c|}
\hline \multirow[b]{3}{*}{ Location Species } & \multicolumn{4}{|c|}{ Crested wheatgrass unit } & \multicolumn{4}{|c|}{ Mixed crested wheatgrass and smooth brome unit } \\
\hline & \multicolumn{2}{|c|}{ Exclosure } & \multicolumn{2}{|c|}{ Grazed } & \multicolumn{2}{|c|}{ Exclosure } & \multicolumn{2}{|c|}{ Grazed } \\
\hline & 1961 & 1967 & 1961 & 1967 & 1961 & 1967 & 1961 & 1967 \\
\hline \multicolumn{9}{|l|}{ Swale } \\
\hline \multicolumn{9}{|c|}{ Herbage production (lb/acre) } \\
\hline Agropyron cristatum & 635 & 718 & 407 & 57 & 3 & 2 & 0 & 0 \\
\hline Agropyron spp. ${ }^{1}$ & 213 & 165 & 293 & 106 & 3 & 3. & 18 & 36 \\
\hline Bromus inermis & 66 & 342 & 120 & 319 & 1009 & 2735 & 354 & 1124 \\
\hline Poa pratensis & 49 & 17 & 25 & 0 & 16 & 74 & 127 & 180 \\
\hline Poa spp. & 0 & 29 & 0 & 101 & 65 & 43 & 6 & 330 \\
\hline Other Grasses & 65 & 85 & 58 & 119 & 33 & 7 & 32 & 262 \\
\hline Aster chilensis & 108 & 74 & 86 & 93 & 0 & 37 & 42 & 128 \\
\hline Astragalus spp. & 0 & 0 & 0 & 0 & 21 & 9 & 13 & 25 \\
\hline Taraxacum officinale & 1 & 1 & 0 & 2 & 38 & 55 & 65 & 128 \\
\hline Other Forbs & 69 & 128 & 86 & 265 & 227 & 51 & 31 & 70 \\
\hline Total grasses & 1028 & 1356 & 903 & 702 & 1129 & 2864 & 537 & 1932 \\
\hline Total forbs & 178 & 203 & 172 & 360 & 286 & 152 & 151 & 351 \\
\hline Total herbage & 1206 & 1559 & 1075 & 1062 & 1415 & 3016 & 688 & 2283 \\
\hline \multicolumn{9}{|c|}{ Aerial cover $(\%)$} \\
\hline Shrub cover & 6 & 6 & 3 & 11 & $\operatorname{Tr}^{2}$ & 0 & 0 & 0 \\
\hline Total plant cover & 36 & 31 & 31 & 39 & 43 & 34 & 32 & 56 \\
\hline Litter & 48 & 59 & 44 & 29 & 51 & 65 & 47 & 22 \\
\hline Bare ground & 16 & 10 & 25 & 32 & 6 & 1 & 18 & 22 \\
\hline \multicolumn{9}{|l|}{ Upland } \\
\hline \multicolumn{9}{|c|}{ Herbage production (lb/acre) } \\
\hline Agropyron cristatum & 1227 & 1542 & 911 & 1596 & 124 & 97 & 194 & 207 \\
\hline Agropyron spp. ${ }^{1}$ & 53 & 14 & 8 & 15 & 51 & 34 & 19 & 43 \\
\hline Bromus inermis & 37 & 9 & 24 & 34 & 278 & 993 & 131 & 651 \\
\hline Poa spp. & 20 & 0 & 3 & 44 & 127 & 51 & 63 & 84 \\
\hline Other Grasses & 1 & 14 & 1 & 35 & 73 & 116 & 105 & 192 \\
\hline Astragalus spp. & 0 & 0 & 0 & 0 & 28 & 45 & 31 & 82 \\
\hline Lupinus caudatus & 0 & 0 & 0 & 0 & 36 & 26 & 50 & 10 \\
\hline Solidago petradoria & 176 & 112 & 165 & 87 & 94 & 15 & 30 & 90 \\
\hline Other Forbs & 6 & 6 & 0 & 15 & 157 & 224 & 180 & 198 \\
\hline Total grasses & 1338 & 1579 & 947 & 1724 & 653 & 1291 & 512 & 1177 \\
\hline Total forbs & 182 & 118 & 165 & 102 & 315 & 310 & 291 & 380 \\
\hline Total herbage & 1520 & 1689 & 1112 & 1825 & 968 & 1601 & 803 & 1547 \\
\hline \multicolumn{9}{|c|}{ Aerial cover $(\%)$} \\
\hline Shrub cover & $\operatorname{Tr}$ & $\operatorname{Tr}$ & 0 & 1 & 14 & 10 & 8 & 11 \\
\hline Total plant cover & 30 & 31 & 25 & 36 & 38 & 35 & 29 & 36 \\
\hline Litter & 45 & 52 & 31 & 49 & 58 & 54 & 57 & 46 \\
\hline Bare ground & 25 & 17 & 44 & 15 & 4 & 11 & 14 & 18 \\
\hline
\end{tabular}

'A. dasystachyum, A. repens, $A$, smithii, and $A$. tricophorum.

${ }^{2} \mathrm{Tr}=$ trace $=$ lcss than $0.5 \%$ cover.

not detrimental to grass production. On the swale plot in the crested wheatgrass unit a slight decline in grass production occurred. However, utilization was no heavier on this plot than on the swale plot in the crested-brome unit so the reason for the decline is not known.

On upland sites in the crested wheatgrass unit, crested wheatgrass remained the dominant species. However, in the crestedbrome unit smooth brome made up only $16 \%$ of the total herbage production of the grazed upland sites in 1961 but increased to $42 \%$ of the total by 1967 . Smooth brome also increased markedly both in production and percentage composition on the swale plot in the crested wheatgrass unit. In the crested-brome unit, smooth brome was the dominant species in the swale, both in 1961 and in 1967.

\section{Shrub and Ground Cover}

The changes in ground cover provided little additional information for interpretation of differences between grazing systems. Total ground cover (plant plus litter) either remained the same or decreased somewhat in all areas in the native units and no differences between systems could be determined (Table 2). Shrub cover (mainly big sagebrush) remained constant in both grazed areas and exclosures in the rest-rotation system and in the grazed areas in summer-long alternate year system. Shrub cover decreased in the exclosures in the latter system but increased in both the exclosures and grazed areas in the unit grazed summer-long every year. Some sagebrush control (probably railing) was done in the early 1950 's in the unit grazed summer-long every year. The increase in sagebrush cover probaly was natural recovery following this control. This finding agrees with that of Hughes (1980), who found that sagebrush return after removal is independent of presence or absence of grazing or type of grazing system.

In the seeded units, total ground cover changed little except for an increase in total ground cover in both grazed areas and exclosures in the upland lots of the crested wheatgrass unit. Sagebrush was beginning to reinvade the upland areas in the crested-brome unit at the start of the study. By 1967, cover of sagebrush had decreased slightly in the exclosures and had increased in the grazed areas in that unit, indicating that grazing may have created conditions favorable for the return of sagebrush on the seeded range because the cattle did not eat the sagebrush even under heavy grazing pressure.

\section{Cattle Weights}

The pattern of weight gains of all cattle on the allotment was 
Table 4. Comparison of a verage cattle weight gains (lb/day) among grazing systems for early summer (July-mid Aug.), late summer (mid Aug.-early Oct.) and all summer on the Diamond Mountain Cattle Allotment, 1961-1965).

\begin{tabular}{|c|c|c|c|c|c|}
\hline \multirow[b]{2}{*}{ Class of cattle } & \multirow[b]{2}{*}{ Period } & \multirow[b]{2}{*}{ Summer-long every year } & \multirow{2}{*}{ Rest-rotation } & \multicolumn{2}{|c|}{ Summer-long, alternate years ${ }^{1}$} \\
\hline & & & & Seeded & Native \\
\hline \multicolumn{6}{|l|}{ Cows } \\
\hline & Early summer & 2.29 & 2.28 & 1.69 & 1.71 \\
\hline & Late summer & 0.68 & 0.44 & 0.63 & 0.68 \\
\hline & All summer & 1.17 & 1.20 & 0.98 & 1.06 \\
\hline \multicolumn{6}{|l|}{ Calves } \\
\hline & Early summer & 2.00 & 2.00 & 1.80 & 2.15 \\
\hline & Late summer & 1.86 & 1.89 & 1.87 & 1.82 \\
\hline & All summer & 1.91 & 1.92 & 1.84 & 1.96 \\
\hline \multicolumn{6}{|l|}{ Yearlings } \\
\hline & Early summer & 1.86 & 1.93 & 1.97 & 1.62 \\
\hline & Late summer & 1.23 & 1.29 & 1.20 & 1.30 \\
\hline & All summer & 1.47 & 1.54 & 1.47 & 1.40 \\
\hline
\end{tabular}

In 1961, 1963, and 1965 grazing was in the crested-brome seeded unit. In 1962 and 1964 grazing was in the native unit.

summarized by Conrad and Laycock (1968). Average weights at the beginning and end of the grazing season for the period 1961-65 were: 865 and $1,049 \mathrm{lb}$ for cows, 624 and $821 \mathrm{lb}$ for yearlings, and 238 and $429 \mathrm{lb}$ for calves. The average pounds of gain per day during the period were:

$\begin{array}{lcccc} & \begin{array}{c}\text { Spring } \\ \text { (June 2- } \\ \text { July 4) }\end{array} & \begin{array}{c}\text { Early summer Late summer } \\ \text { (July 5- }\end{array} & \begin{array}{c}\text { (Aug. 12- } \\ \text { Aug. 11) }\end{array} & \begin{array}{c}\text { Entire } \\ \text { Oct. 5) }\end{array} \\ \text { Season } \\ \text { Cows } & 2.4 & 2.2 & 0.5 & 1.5 \\ \text { Yalves } & 1.8 & 2.0 & 1.8 & 1.9 \\ \text { Yearlings } & 1.8 & 1.8 & 1.3 & 1.6\end{array}$

Average daily weight gains for the entire season did not differ significantly among years for any class of cattle. Weight gains for the entire study period were not significantly different between the spring (June) and early summer periods for any class of cattle. However, in some years weight gains of cows and heifers were significantly greater in the spring; in other years, gains were greater in early summer. This probably resulted from either the condition of the cattle or the growth stage of the vegetation at the time the cattle entered the allotment each year. Cows and yearlings gained significantly less in late summer than earlier in the season. The reduction in gain was less for heifers than for cows. Calves maintained relatively uniform weight gains during the spring and summer every year.
In our study calves gained the same and cows gained about double the amounts reported by Harris and Driscoll (1954) on ponderosa pine summer range in Oregon.

\section{Differences between the Summer Grazing System}

For the entire study period there were no differences in daily gains among grazing systems for the two summer grazing periods or for the entire summer (Table 4). For cows and yearlings, some differences did occur among systems in specific years but no pattern was present. For example, in late summer in 1961 and 1963, cows gained less in the rest-rotation system than in either of the summer-long systems. However, in 1961 cows gained more in late summer in the rest-rotation system than in the other two systems. These differences may relate to relative degree of utilization among systems in particular years. For example, in 1962 the grass in the unit of the rest-rotation system grazed in late summer was utilized $28 \%$ while the utilization in the other two systems was $34-35 \%$.

The daily gains from this study were similar to those reported by Smith et al. (1967) for cattle on high elevation summer ranges in the Big Horn Mountains in Wyoming. They also found no differences in daily gains of steers on units grazed under season-long use and gains on units grazed under a rotation system.

\section{Gain per Acre}

The only statistic indicating any differences among grazing sys-

Table 5. Comparisons of average cattle gains, acres/Animal Unit Month (AUM), grass production, and utilization in different grazing systems, Diamond Mountain Cattle allotment, 1961-1965.

\begin{tabular}{|c|c|c|c|c|c|c|c|c|c|c|c|}
\hline \multirow[b]{2}{*}{$\begin{array}{l}\text { Season of grazing } \\
\text { and range type }\end{array}$} & \multirow[b]{2}{*}{ Grazing system } & \multicolumn{3}{|c|}{$\begin{array}{c}\text { Average daily gain (lb) } \\
\text { per head }\end{array}$} & \multicolumn{2}{|c|}{$\begin{array}{l}\text { Average gain (lb ) } \\
\text { per acre-all animals }\end{array}$} & \multicolumn{2}{|c|}{ Acres per AUM } & \multirow{2}{*}{$\begin{array}{c}\text { Grass } \\
\text { production } \\
\text { (lb/acre) } \\
\text { Upland } \\
\text { sites } \\
\\
1967\end{array}$} & \multicolumn{2}{|c|}{$\begin{array}{l}\text { Average utilizatio } \\
(\%) \text { of grass }\end{array}$} \\
\hline & & Cows & Calves & Yearlings & $\begin{array}{l}\text { Units } \\
\text { grazed }\end{array}$ & $\begin{array}{l}\text { All units } \\
\text { for all years }\end{array}$ & $\begin{array}{l}\text { Years } \\
\text { grazed }\end{array}$ & $\begin{array}{c}\text { All } \\
\text { years }\end{array}$ & & $\begin{array}{l}\text { Years } \\
\text { grazed }\end{array}$ & $\begin{array}{l}\text { All } \\
\text { years }\end{array}$ \\
\hline \multirow[t]{2}{*}{$\begin{array}{l}\text { Spring (June) } \\
\text { seeded range }\end{array}$} & $\begin{array}{l}2 \text { units grazed in } \\
\text { alternate years }\end{array}$ & 2.38 & 1.83 & 1.81 & 40.6 & 20.1 & 2.5 & 5.0 & 1450 & 50 & 25 \\
\hline & Rest-rotation & 1.20 & 1.93 & 1.54 & 17.1 & 11.3 & 3.8 & 5.9 & 390 & 37 & 25 \\
\hline \multirow[t]{2}{*}{$\begin{array}{l}\text { Summer } \\
\text { (July-Sept.) } \\
\text { native range }\end{array}$} & $\begin{array}{l}\text { Summer-long } \\
\text { every year }\end{array}$ & 1.17 & 1.91 & 1.47 & 18.3 & 18.3 & 3.7 & 3.7 & 478 & 37 & 37 \\
\hline & $\begin{array}{l}\text { Summer-long } \\
\text { alternate years }\end{array}$ & .98 & 1.96 & 1.44 & 19.0 & 9.5 & 4.0 & 8.0 & 505 & 44 & 22 \\
\hline $\begin{array}{l}\text { Summer } \\
\text { (July-Sept.) } \\
\text { seeded range }\end{array}$ & $\begin{array}{l}\text { Summer-long } \\
\text { alternate years }\end{array}$ & 1.06 & 1.84 & 1.44 & 17.9 & 9.0 & 3.9 & 7.8 & $530^{1}$ & 55 & 28 \\
\hline
\end{tabular}

'Amount of grass estimated to remain after heavy spring grazing. 
tems was gain per acre summed for all classes of cattle. However, gain per acre figures can be misleading unless careful comparisons are made that include stocking rate and amount of utilization. When just the units grazed each year were used in the computation, the average gain per acre was more than twice as high on the seeded units grazed in the spring as for the native units grazed during the summer (Table 5). This comparison was confounded by time of grazing, however, because gains almost always tend to be higher early in the season than in late summer as a result of less herbage of poorer quality in late summer.

When only those units actually grazed are considered, the three grazing systems on native range had similar gains per acre. When the units rested are included in the computations, the gain per acre in the unit grazed summer-long every year was almost as high as the average gain per acre in the seeded units and was twice that of the rest-rotation and the summer-long alternate years systems.

The comparison on native range was confounded by differential grazing pressure (as indicated by utilization) in the three systems. Average utilization over all years in the unit grazed summer-long every year was $48 \%$ higher than utilization in the rest-rotation system and $68 \%$ higher than the unit grazed summer-long in alternate years. If stocking had been such as to achieve the same average utilization and if gain per head had been the same under the heavy stocking, the gains per acre in the various systems would have been much closer. However, studies in other areas (Frischknecht and Harris 1968; Hargrave 1949, McIlvain and Savage 1951) have reported that moderate to heavy summer-long grazing generally produces greater daily gains than does rotation grazing.

\section{Discussion}

\section{Native Range}

The reader should be aware that treatments in this study were not replicated in space. All systems were repeated in time, i.e., the 3 -unit system was repeated twice and the 2 -unit systems were repeated 3 times during the course of the study. Based on the available data, trends in production or composition of vegetation showed no consistent differences between rest-rotation grazing, grazing summer-long every year, and grazing summer-long in alternate years. Earlier studies indicated that grazing on the allotment caused no measureable increases in soil bulk density in the native units (Laycock and Conrad 1967).

Daily weight gains of all classes of cattle were the same for all grazing systems. However, weight gain per acre, based on all the area assigned to a grazing system, including areas not grazed, indicated a superiority of the system grazed summer-long every year. Gain per acre figures can be misleading because high gains per acre resulting from too-heavy grazing can lead to deterioration of the range. However, none of the grazing systems tested significantly affected either the vegetation or the soil. This indicated that, for the area and degree of forage utilization studied, grazing native ranges summer-long every year will produce more beef per acre than rest-rotation or summer-long, alternate year systems with no damage to the soil or vegetation resource. The cost of the additional fencing needed for a rest-rotation system and not needed for a summer-long system must also be considered in an economic analysis of the systems. In other areas or under equal or heavier grazing intensities, the results might be different.

In many situations when a rest-rotation system is to be applied, fences are built; water is developed; and salting, riding, and other management is intensified. Then, if a favorable response in the vegetation is detected, the tendency is to say- "Look what restrotation has done for this range." In reality, the proper statement is-"Look what good range management has done." In this study, units in all systems had adequate and well-distributed water, good distribution of salt, and adequate riding at the same intensity for all systems.

In spite of the fact that rest-rotation systems has been widely applied, especially on federally owned land in the Western United States, few controlled studies have been made comparing restrotation with other systems. The only attempt at evaluation of a est-rotation system on mountain rangelands found in the literature was published by Johnson (1965) on mountain grassland shrub vegetation in the Medicine Bow Mountains of Southeastern Wyoming. Rotation (4 units) and rest-rotation (4 units) grazing during the summer were reported to have significantly reduced utilization of grasses. The biggest reduction resulted from the rest-rotation system where utilization during treatment was about one-half that during pre-treatment summer-long grazing. No cxplanation was given for the great reduction in utilization. After 4 years, plant cover was about the same under the rotation system but increased under the rest-rotation system. Stocking rates were much lighter in the rest-rotation system than in the rotation system.

Evaluations of the original rest-rotation study at Harvey Valley, California, contained many inconsistencies and the results are not as significant as might be expected (Hormay 1970, Hormay and Talbot 1961, Hormay and Evanko 1958, Ratliff ct al. 1972). Evaluations of other rest-rotation systems have been equally unconvincing. Ratliff et al. (1972) cited an example of "A 10-percent increase in the allowable number of cattle after only 1 year of rest-rotation grazing. This was on a rangc grazed yearlong and with only 9 inches of precipitation annually." No system can be evaluated after only 1 year to determine if it has increased carrying capacity, especially in a low rainfall area where vegetation responses tend to be slow. Hughes (1979) found that rest-rotation systems in the Arizona strip caused undesirable changes in species composition if average utilization exceeded $55 \%$. Use exceeding this caused deterioration regardless of the management system. In the same area, Hughes (1980) found that grazing systems, including rest-rotation, failed to prevent return of sagebrush following removal.

Range managers should apply grazing systems that produce the most red meat in the most economical manner, while preserving the productivity, watershed, open space, wildlife values, and other attributes of ranges in good condition. If the best system for a given range type is a relatively complex system, like rest-rotation, then it should bc uscd. If a simpler system gets equally good or better results, then it should be used.

\section{Seeded Range}

The heavy grazing in alternate years maintained or increased production of the introduced grasses in both seeded units. Even heavy grazing in the spring failed to cause measureable increases in soil bulk density in the seeded units (Laycock and Conrad 1967). In the crested wheatgrass unit, grazing systems that have been used successfully in other areas and that call for moderate to heavy use more frequently than every other year, probably could have been uscd. In Utah, Frischknecht and Harris (1968) found that $65 \%$ annual spring use of crested wheatgrass caused no major damage to the stands. Springfield (1963) found that $65-70 \%$ use of crested wheatgrass annually maintained the stands and produced satisfactory cattle gains. In Saskatchewan, a crested wheatgrass pasture utilized an average of $70 \%$ in early summer was more productive at the end of a 6-year period than a pasture grazed an average of $50 \%$ (Lodge, Smoliak, and Johnston 1972). Fifty \% use of crested wheatgrass in Idaho likewise produced favorable results (Sharp 1970). The high-producing crested wheatgrass stand on the Diamond Mountain Cattle Allotment probably could withstand reasonably heavy grazing more often than every other year.

In the crested-brome unit, the heavy grazing in alternate years not only increased grass production but it also solved the problem of poor utilization of crested wheatgrass that occurred with moderate grazing. When the gain per acre figures for the combined spring and summer grazing periods are added (Table 5), the average amount of beef produced per year in this unit was almost 30 pounds per acre, even when the alternate years of rest were considered. This was much higher than the gain per acre figures for any other unit or system in the study and was accomplished with increased production and improved composition of the vegetation. Some system similar to that studied probably should be recom- 
mended for high elevation pastures with a mixed smooth bromecrested wheatgrass composition.

\section{Literature Cited}

Conrad, P.W., and W.A. Laycock. 1968. Cattle weight gains on mountain ranges in eastern Utah. West. Livestock J. 47(5):12-15.

Frischknecht, N.C., and L.E. Harris. 1968. Grazing intensities and systems on crested wheatgrass in central Utah: Response of vegetation and cattle. U.S. Dep. of Agr. Tech. Bull. 1388, 47 p.

Hargrave, H.J. 1949. Dominion Range Experiment Station, Manyberries Alberta. Progr. Rep. (1937-1949) Dominion Dep. Agr., Ottawa, Ontario.

Harris, R.W., and R.S. Driscoll. 1954. Gains made by cattle on summer range. Oregon Cattleman 3(5):5,24.

Hormay, A.L. 1970. Principles of rest-rotation grazing and multiple-use land management. U.S. Dep. of Interior and U.S. Dep. of Agr. Bull. TT-4, 26 p.

Hormay, A.L., and A.B. Evanko. 1958. Rest-rotation grazing. . . a management system for bunchgrass ranges. U.S. Dep. of Agr., California Forest and Range Experiment Station, Paper No. 27, 11 p.

Hormay, A.L., and M.W. Talbot. 1961. Rest-rotation grazing. . A new management system for perennial bunchgrass ranges. U.S. Dep. Agr., Forest Service, Prod. Res. Rep. No. 51, 43 p.

Hughes, L.E. 1979. Rest-rotation grazing on the Arizona Strip: an observation. Rangelands 1:106-108.

Hughes, L.E. 1980. Six grazing exclosures with a message. Rangelands 2:17-18.
Johnson, W.M. 1965. Rotation, rest-rotation, and season-long grazing on a mountain range in Wyoming. U.S. Dep. of Agr., Forest Service, Res. Paper RM-14, 16 p.

Laycock, W.A., and P.W. Conrad. 1967. Effect of grazing on soil compaction as measured by bulk density on a high elevation cattle range. $J$. Range Manage. 20:136-140.

Lodge, R.W., S. Smoliak, and A. Johnston. 1972. Managing crested wheatgrass pastures. Agriculture Canada Pub. 1473. 20 p.

Mcllvain, E.H., and D.A. Savage. 1951. Eight-year comparisons of continuous and rotational grazing on the Southern Plains Experimental Range. J. Range Manage. 4:42-47.

Pechanec, J.F., and G.D. Pickford. 1937. A comparison of some methods used in determining percentage utilization of range grasses. J. Agr. Res. 54:753-765.

Ratliff, R.D., J.N. Reppert, and R.J. McConnen. 1972. Rest-rotation grazing at Harvey Valley...range health, cattle gains, costs. U.S. Dep. of Agr., Forest Service, Res. Paper PSW-77, 24 p.

Sharp, L.A. 1970. Suggested management programs for grazing crested wheatgrass. Forest, Wildlife and Range Exp. Sta., Univ. of Idaho. Bull. $4,19 \mathrm{p}$.

Smith, D.R., H.G. Fisser, N. Jefferies, and P.O. Stratton. 1967. Rotation grazing on Wyoming's Big Horn Mountains. Agr. Exp. Sta., Univ. of Wyoming. Res. J. 13, 26 p.

Springfield, H.W. 1963. Cattle gains and plant responses from spring grazing on crested wheatgrass in northern New Mexico. U.S. Dep. of Agr., Forest Service, Prod. Res. Rep. 74, 46 p. 